(c) American Dairy Science Association, 2005.

\title{
Effect of Fibrolytic Enzymes on the Fermentation Characteristics, Aerobic Stability, and Digestibility of Bermudagrass Silage
}

\author{
D. B. Dean, ${ }^{1,3}$ A. T. Adesogan, ${ }^{1}$ N. Krueger, ${ }^{1}$ and R. C. Littell ${ }^{2}$ \\ ${ }^{1}$ Department of Animal Sciences, Institute of Food and Agricultural Sciences, \\ University of Florida, PO Box 110910, Gainesville, 32611 \\ ${ }^{2}$ Department of Statistics, Institute of Food and Agricultural Sciences, \\ PO Box 110339 University of Florida, Gainesville, 32611 \\ ${ }^{3}$ La Universidad del Zulia, Facultad de Ciencias Veterinarias, Maracaibo, Venezuela
}

\begin{abstract}
The aim of this study was to determine if the nutritive value and aerobic stability of bermudagrass (Cynodon dactylon) silage could be improved by addition of proprietary, exogenous cellulase/hemicellulase enzyme preparations at ensiling. A 5-wk regrowth of Tifton 85 bermudagrass was conserved without treatment (control) or after treatment with exogenous fibrolytic enzymes including Promote NET (Pr), Biocellulase X-20 (X20), Biocellulase A-20 (A20), and Enzyme CT. The respective enzymes were applied at half the recommended rate, the recommended rate, or twice the recommended rate corresponding to $0.65,1.3$, and $2.6 \mathrm{~g} / \mathrm{kg}$ of $\mathrm{DM}, 7.3$, 14.5 , and $29 \mathrm{mg} / \mathrm{kg}$ of DM, at $7.3,14.4$, and $29 \mathrm{mg} / \mathrm{kg}$ of DM, and 89, 178, and $356 \mathrm{mg} / \mathrm{kg}$ of DM, for Pr, X20, $\mathrm{A} 20$, and CT, respectively. The enzymes were sprayed on the bermudagrass at ensiling (not added at feeding as suggested by the manufacturers) to test the objectives of the study. Six 1-kg replicates of chopped $(5 \mathrm{~cm})$ forage were ensiled for $145 \mathrm{~d}$ in 2.8 -L mini silos. Three silos per treatment were used for chemical analysis and 3 for aerobic stability monitoring. The silage juice was analyzed for organic acids, $\mathrm{pH}$, water-soluble carbohydrates (WSC), ammonia-N, and soluble N. Freeze-dried samples were analyzed for crude protein (CP), neutral detergent fiber (NDF), and acid detergent fiber (ADF). In vitro digestibility of DM (IVDMD), NDF (IVNDFD), and ADF (IVADFD) were determined after digesting the silages in buffered rumen fluid for 6 or $48 \mathrm{~h}$ in 2 ANKOM $^{\mathrm{II}}$ Daisy Incubators. Compared with the other silages, those treated with Pr had lower DM losses, and lower $\mathrm{pH}$ and ammonia-N concentration than control silages. Residual WSC concentration was greater in Pr- and CT-treated silages than in control silages and greater in Pr-treated silages than CT-treated silages.
\end{abstract}

Received August 31, 2004.

Accepted November 19, 2004.

Corresponding author: Adegbola T. Adesogan; e-mail: adesogan @animal.ufl.edu.
Compared with control silages, NDF concentration was lower in silages treated with $\mathrm{Pr}, \mathrm{X} 20$, and CT, and $\mathrm{ADF}$ concentration was lower in silages treated with $\mathrm{Pr}, \mathrm{X} 20$, and A20. Nevertheless, Pr-treated silages contained lower $\mathrm{ADF}$ and $\mathrm{NDF}$ concentrations than silages treated with the other enzymes. Enzyme-treated silages contained less acetic acid than control silages, and Pr-treated silages had the lowest concentrations of acetic acid. Aerobic stability was increased by enzyme treatment but microbial counts were not affected. The 6-h IVDMD was increased by treatment with Pr and A20, however only Pr increased the IVDMD and IVNDFD at $48 \mathrm{~h}$. The 48 -h IVADFD was also increased by treatment with Pr, CT, and A20. These results show that when applied at ensiling, certain fibrolytic enzymes (particularly Promote) can improve the digestibility, fermentation, and aerobic stability of bermudagrass silage.

(Key words: fibrolytic enzyme, bermudagrass, silage, nutritive value)

Abbreviation key: A20 = Biocellulase A-20 enzyme preparation, $\mathbf{C T}=$ CT enzyme preparation, $\mathbf{P r}=$ Promote enzyme preparation, X20 = Biocellulase X-20 enzyme preparation, $\mathbf{W S C}$ = water-soluble carbohydrates, WSN = water-soluble $\mathbf{N}$.

\section{INTRODUCTION}

Interest in applying fibrolytic enzymes to ruminant diets has increased recently due to enzyme-mediated increases in feed digestion in vitro (Lewis et al., 1996; Hristov et al., 2000; Bowman et al., 2002; Kung et al., 2002) and diet use in vivo (Lewis et al., 1996; Schingoethe et al., 1999; Yang et al., 1999). However, in certain studies (Sheperd and Kung, 1996b; Bowman et al., 2002; Vicini et al., 2003) exogenous enzyme supplementation did not consistently improve animal performance. Where improved performance was observed, the mechanism was not always confirmed by improved digestion (Mandebvu et al., 1999). These inconsistencies were due to various factors such as enzyme type, con- 
centration and activity, application method, substrate to which enzyme is added, and animal differences (Bowman et al., 2002). Additional factors that may be implicated include prevailing temperature and $\mathrm{pH}$, presence of cofactors and inhibitors, and enzyme and substrate concentration. Nevertheless, feed enzymes have been used to improve the use of a wide range of diets containing legumes, grasses, haylage, straw, and other feedstuffs (Beauchemin et al., 2003). The mode of action of these enzymes in ruminants is not fully understood. They can enhance feed colonization by increasing the numbers of ruminal fibrolytic microbes (Morgavi et al., 2000; Nsereko et al., 2000) and thus, can increase the rate of degradation in the rumen (Yang et al., 1999). Enzymes can also partially solubilize NDF and ADF, and release reducing sugars in the process. Colombatto et al. (2003) observed that fibrolytic enzymes enhanced the fermentation of cellulose and xylan by a combination of pre- and postincubation effects. These were evident from an increase in the release of reducing sugars during a 20 -h preincubation phase and an increase in the hydrolytic activity of the liquid and solid fractions of the ruminal fluid $6 \mathrm{~h}$ after incubation, which led to a higher rate of fermentation. Most of the studies on fibrolytic enzyme treatment of ruminant feeds have been done using temperate feedstuffs. Little is known about their effectiveness on tropical or subtropical forages, which tend to be poorly digested. The objective of this experiment was to evaluate the effect of 4 proprietary fibrolytic enzyme preparations applied at different rates, at ensiling, on the nutritive value of Tifton-85 bermudagrass silage. Most of the recent studies in this area have involved enzyme application to individual components of the ration or to the total ration just before feeding. There were 2 reasons for applying the enzymes directly to bermudagrass at the point of ensiling in this study. Firstly, we sought to determine if the sugars produced by enzymatic cell wall hydrolysis would improve the fermentation of bermudagrass (which is typically poor) and decrease DM losses, which are typically high for this forage. Secondly, we wanted to determine the effectiveness of the enzymes at improving the digestibility of the forage, because although bermudagrass is poorly digested, it is an important digestible fiber source in the rations of dairy cows in the southeast.

\section{MATERIALS AND METHODS}

\section{Enzyme Application}

A 5-wk regrowth of Tifton-85 bermudagrass (Cynodon dactylon) silage was conserved without treatment (control) or after treatment with 4 proprietary fibrolytic enzymes. The enzymes were applied at half $(0.5 \times)$, ex- actly (1×), or twice $(2 \times)$ the rates recommended by the respective manufacturers for addition at the time of feeding. Because the enzymes were applied at ensiling rather than at feeding as recommended by the manufacturers, the study was not designed to test the effectiveness of the enzymes as used commercially, and the results should not be misconstrued as such. The rationale for the mode of enzyme application was to determine if the fermentation and digestibility of bermudagrass could be improved by enzyme addition. The enzymes used were: 1) Promote NET (Pr; Cargill Corp., St. Louis, MO) applied at $0.65,1.3$, and $2.6 \mathrm{~g} / \mathrm{kg}$ of DM, 2) Biocellulase X-20 (X20, LodeStar, IL) applied at 7.3, 14.5, and $29 \mathrm{mg} / \mathrm{kg}$ of DM, 3) Biocellulase A-20 (A20, LodeStar, IL) applied at 7.3, 14.4, and $29 \mathrm{mg} / \mathrm{kg}$ of DM, and, 4) Enzyme CT (CT) applied at 89, 178, and $356 \mathrm{mg} / \mathrm{kg}$ of DM. Cellulase activity was determined at $39^{\circ} \mathrm{C}$ and pH 5.5 using the filter paper method (Wood and Bhat, 1988), and the values obtained for Pr, X20, CT, and A20 were 33.7, 22, 0, and 51.3 filter paper units/g, respectively. Xylanase activity was determined at $39^{\circ} \mathrm{C}$ and $\mathrm{pH} 5.5$ using the di-nitro salicyclic acid procedure (Bailey et al., 1992), and the values obtained for $\mathrm{Pr}$, $\mathrm{X} 20, \mathrm{CT}$, and A20 were 5190, 7025, 0, and $3530 \mu \mathrm{mol} /$ min per $\mathrm{mL}$, respectively. The units of xylanase activity are expressed as micromoles of xylose equivalents released per milliliter per minute from $1 \%$ birchwood xylan (X-0502, Sigma Chemical Co., St. Louis, MO).

Each enzyme was dissolved in $400 \mathrm{~mL}$ of water and sprayed in a fine mist, using a 1-gal garden sprayer, over $10 \mathrm{~kg}$ of chopped $(5 \mathrm{~cm})$ forage per treatment. The same amount of water was sprayed on the control forages. After thorough mixing, a 1-kg representative sample of the treated forage was ensiled within a polythene bag in 6 replicate 2.8-L polyvinyl chloride cylindrical mini silos. A hydraulic press was used to compress the forage in the silo to achieve a density of 280 $\mathrm{kg} / \mathrm{m}^{3}$. Weights of the empty and full silos were recorded, and silos were then stored for $145 \mathrm{~d}$ at ambient temperature $\left(23\right.$ to $\left.27^{\circ} \mathrm{C}\right)$ in a covered barn. Representative samples $(4 \mathrm{~kg})$ of the freshly treated, unensiled forages were frozen $\left(-20^{\circ} \mathrm{C}\right)$ for subsequent laboratory analysis.

\section{Laboratory Analysis}

At silo opening, final silo weights were recorded and silages from each of 3 silos per treatment were subsampled for DM determination (200 g) and silage juice extraction $(200 \mathrm{~g})$ or freeze-dried for chemical analysis $(200 \mathrm{~g})$. Each of the other 3 silos was subsampled for microbial enumeration (200 g) and aerobic stability (800 g). Samples destined for microbial analysis were 
heat-sealed within gas-impermeable bags (Kapak/ Scotch Pak, Kapak Corp., Minneapolis, MN), placed in an icebox, and dispatched the same day to the American Bacteriological and Chemical (ABC) Research Corporation, Gainesville, FL. Serial dilutions up to $1 \times 10^{10}$ were made using $25 \mathrm{~g}$ of silage and Butterfields' phosphate buffer. Yeast and molds were enumerated by pour plating in Standard Methods (M124) agar, to which 40 ppm of chloramphenicol and chlortetracycline were added (Tournas et al., 1998). Plates were incubated aerobically at $25^{\circ} \mathrm{C}$ for $5 \mathrm{~d}$. Aerobic stability was measured by placing thermocouple wires at the center of a bag containing $800 \mathrm{~g}$ of silage, within an open-top polystyrene box. The silages were covered with 2 layers of cheesecloth to prevent drying. The thermocouple wires were connected to data loggers (Campbell Scientific Inc., North Logan, UT) that recorded the temperature every $30 \mathrm{~min}$ for $30 \mathrm{~d}$. Aerobic stability was denoted by the time taken (h) for a $2^{\circ} \mathrm{C}$ rise in silage temperature above ambient temperature $\left(23\right.$ to $\left.27^{\circ} \mathrm{C}\right)$. Dry matter losses were estimated using DM concentrations and silo weights measured before and after ensiling. Oven DM concentration was determined in a forced draft oven at $60^{\circ} \mathrm{C}$ for $48 \mathrm{~h}$. Ash concentration was determined in a muffle furnace at $500^{\circ} \mathrm{C}$ for $5 \mathrm{~h}$. Silage juice was obtained by blending $20 \mathrm{~g}$ of silage in $200 \mathrm{~mL}$ of distilled water for $30 \mathrm{~s}$ at high speed and filtering the slurry through 2 layers of cheesecloth. The $\mathrm{pH}$ was measured using a pH meter (Corning model 12, Corning Scientific Instruments, Medfield, MA). The filtrate was centrifuged at $4^{\circ} \mathrm{C}$ and $21,500 \times \mathrm{g}$ for $20 \mathrm{~min}$ and the supernatant was frozen $\left(-20^{\circ} \mathrm{C}\right)$ in 20 - $\mathrm{mL}$ vials for subsequent analysis of lactic acid, VFA, water-soluble carbohydrates (WSC), ammonia nitrogen $\left(\mathrm{NH}_{3}-\mathrm{N}\right)$, and watersoluble N (WSN).

Organic acids were measured using the method of Muck and Dickerson (1988) and an HPLC system (Hitachi, FL 7485, Tokyo, Japan) coupled to a UV detector (Spectroflow 757, ABI Analytical Kratos Division, Ramsey, NJ) set at $210 \mathrm{~nm}$. The column used was a BioRad Aminex HPX-87H (Bio-Rad Laboratories, Hercules, CA) with $0.015 M$ sulfuric acid as the mobile phase and a flow rate of $0.7 \mathrm{~mL} / \mathrm{min}$ at $45^{\circ} \mathrm{C}$. Ethanol was measured by gas chromatography using the procedure of Yomano et al. (1998) with a Varian Star 3400 CX gas chromatograph (Varian, Santa Clarita, CA). The anthrone reaction assay (MAFF, 1986) was used to quantify WSC. Ammonia N was determined using an adaptation for the Technicon Auto Analyzer (Technicon, Tarrytown, NY) of the Noel and Hambleton (1976) procedure. Water-soluble $\mathrm{N}$ was determined by digesting $10 \mathrm{~mL}$ of supernatant using micro-Kjeldahl apparatus (Labconco Corporation, Kansas City, MO), and the $\mathrm{N}$ concentration was determined using a Technicon auto analyzer.

Freeze-dried ground $(1 \mathrm{~mm})$ samples were analyzed for $\mathrm{CP}$, in vitro digestibility, $\mathrm{ADF}$, and $\mathrm{NDF}$. In vitro digestibility of DM (IVDMD), NDF (IVNDFD), and ADF (IVADFD) were determined after incubating forage samples in buffered rumen fluid for 6 or 48 h using 2 ANKOM $^{\mathrm{II}}$ Daisy Incubators (ANKOM Technology, Macedon, NY). The buffer was prepared according to the ANKOM Technology procedure. The rumen fluid was obtained before feeding from 2 nonlactating, fistulated cows, fed $9 \mathrm{~kg}$ of coastal bermudagrass (Cynodon dactylon) and $400 \mathrm{~g}$ of soybean meal daily. The NDF and ADF concentrations (Van Soest et al., 1991) of the samples and digested residues were determined without amylase pretreatment using an $\mathrm{ANKOM}^{200}$ Fiber Analyzer (ANKOM Technology). Hemicellulose was calculated as the difference between NDF and ADF concentrations.

\section{Statistical Analysis}

A completely randomized design and a $4 \times 4$ factorial arrangement of enzyme types and application rates with 3 replicates per treatment was used. The data were analyzed using the GLM procedure of SAS (SAS Inst., Inc., Cary, NC). Polynomial contrasts were used to test the effect of increasing enzyme application rate, and orthogonal contrasts were used to compare the control and enzyme treatments. The model used to analyze individual treatment effects was: $\mathrm{Y}_{\mathrm{ij}}=\mu+\mathrm{T}_{\mathrm{i}}+\mathrm{E}_{\mathrm{ij}}$; where $\mu=$ general mean; $\mathrm{T}_{\mathrm{i}}=$ effect of treatment (enzyme type $\times$ enzyme rate); and $E_{\mathrm{ij}}=$ experimental error. Significance was declared at $P<0.05$ and tendencies at $P$ $<0.10$.

\section{RESULTS AND DISCUSSION}

\section{Chemical Composition of Freshly Treated Bermudagrass Before Ensiling}

Table 1 shows the chemical composition of the bermudagrass forages before ensiling. The concentrations of the measured chemical components were similar for all treatments. This is probably attributable to the short duration of enzyme action due to placement of the freshly treated samples on ice after enzyme application. The DM concentration at harvest was similar to that at which bermudagrass is ensiled in Florida, and similar to that $(324 \mathrm{~g} / \mathrm{kg})$ reported for bermudagrass harvested at an equivalent maturity stage by Umana et al. (1991) and Adesogan et al. (2004). The low WSC and $\mathrm{CP}$ concentrations and high NDF and ADF concentrations are also typical of bermudagrass (Umana et al., 1991; Adesogan et al., 2004). These results indicate that 
Table 1. Chemical composition of bermudagrass forages before ensiling ( $\mathrm{g} / \mathrm{kg}$ of DM).

\begin{tabular}{llllllllll}
\hline $\begin{array}{l}\text { Enzyme } \\
\text { treatment }^{1}\end{array}$ & $\begin{array}{l}\mathrm{DM} \\
(\mathrm{g} / \mathrm{kg})\end{array}$ & $\mathrm{pH}$ & $\mathrm{Ash}$ & $\mathrm{WSC}^{2}$ & $\mathrm{NH}_{3}-\mathrm{N}^{3}$ & $\mathrm{CP}$ & $\mathrm{NDF}$ & $\mathrm{ADF}$ & $\mathrm{Hem}^{4}$ \\
\hline Control & 305 & 5.97 & 57 & 6.93 & 54 & 105 & 786 & 436 & 350 \\
$\mathrm{Pr}$ & 302 & 6.42 & 59 & 6.14 & 43 & 99 & 776 & 428 & 348 \\
X20 & 305 & 6.14 & 55 & 6.79 & 56 & 97 & 791 & 440 & 351 \\
$\mathrm{CT}$ & 303 & 5.67 & 62 & 5.83 & 37 & 97 & 786 & 440 & 346 \\
$\mathrm{~A} 20$ & 306 & 6.04 & 57 & 6.67 & 44 & 97 & 791 & 438 & 353 \\
$P$ & 0.836 & 0.795 & 0.762 & 0.717 & 0.758 & 0.504 & 0.264 & 0.236 & 0.547 \\
SE & 4.26 & 0.73 & 6.67 & 1.01 & 18.52 & 4.01 & 8.65 & 6.61 & 5.50 \\
Contrasts & & & & \multicolumn{7}{c}{$P$ values } & & & \\
\hline Control vs. Pr & 0.559 & 0.607 & 0.834 & 0.516 & 0.631 & 0.209 & 0.331 & 0.325 & 0.609 \\
Control vs. X20 & 0.999 & 0.846 & 0.834 & 0.911 & 0.939 & 0.136 & 0.608 & 0.614 & 0.919 \\
Control vs. CT & 0.744 & 0.729 & 0.508 & 0.371 & 0.441 & 0.136 & 0.999 & 0.586 & 0.514 \\
Control vs. A20 & 0.896 & 0.933 & 0.999 & 0.828 & 0.642 & 0.110 & 0.630 & 0.833 & 0.614 \\
\hline
\end{tabular}

${ }^{1}$ Cellulase-hemicellulase preparations: Pr = Promote; X20 = Biocellulase X-20; CT = Enzyme CT; A20 = Biocellulase A-20.

${ }^{2} \mathrm{WSC}=$ Water-soluble carbohydrates.

${ }^{3}$ Ammonia-N expressed as $\mathrm{g} / \mathrm{kg}$ of total N.

${ }^{4} \mathrm{Hem}=$ Hemicellulose.

the bermudagrass was representative of that used for dairy production in the southeastern US.

\section{Chemical Composition, Microbial Counts, and Aerobic Stability of Bermudagrass Silages}

Neither enzyme type nor application rate affected $(P$ $>0.05)$ the DM concentration of the silages. Dry matter values ranged between 296 and $308 \mathrm{~g} / \mathrm{kg}$ (Table 2). The $\mathrm{pH}$ of Pr-treated silages was lower $(P<0.01)$ than that of all other silages; the other enzyme-treated silages had similar $\mathrm{pH}$ values to control silages. This suggests that compared with the other forages, Pr was more effective at increasing the availability of WSC for microbial fermentation, through cell wall hydrolysis. Though this is not evident from the WSC concentration of the freshly treated forages due to the short duration allowed for enzyme action, Pr-treated silages did have greater $(P<0.05)$ residual WSC concentration than the other silages (Table 3$)$. Silage $\mathrm{pH}$ also decreased $(P<$ 0.01 ) linearly as the rate of Pr application increased. The Pr-treated silages had $\mathrm{pH}$ values similar to or lower than that required for achieving stability during fermentation (Bates et al., 1989). Similar reductions in $\mathrm{pH}$ were obtained when fibrolytic enzymes were applied to wheat silage (Adogla-Bessa et al., 1999), corn silage (Sheperd and Kung, 1996a; Colombatto et al., 2004), or orchardgrass and alfalfa silages (Nadeau et al., 2000).

Ammonia-N levels were lower in the Pr-treated silages $(P<0.01)$ than in the other silages. This reveals that less proteolysis occurred during ensiling in Prtreated silages than in other silages, and this was probably due to a faster $\mathrm{pH}$ decline in Pr-treated silages. The lower ammonia-N concentration of Pr-treated silages contrasts with previous studies in which ammonia-N concentration of silages was unaffected by fibrolytic enzyme application (Sheperd and Kung, 1996a; AdoglaBessa et al., 1999).

Yeast and mold counts were unaffected by enzyme type or rate, and the numbers found were below the level $(5.0 \mathrm{cfu} / \mathrm{g})$ that would predispose to rapid deterioration in silage (Kung, 2004). These low yeast and mold counts reflect the antimycotic properties of the VFA produced during the ensiling process (Table 4). Yeasts usually initiate aerobic deterioration of silages, and molds continue the deterioration process, because yeasts grow faster but tolerate less heat than do molds (Higginbotham et al., 1998).

Aerobic stability was increased $(P<0.05)$ by enzyme treatment and such increases were linear $(P<0.05)$ as the rate of enzyme application increased except in X20treated silages. Silages treated with A20 enzyme tended $(P<0.06)$ to be more stable than other additivetreated silages. Nevertheless, all the forages were stable for at least $4 \mathrm{~d}$, such that all of them would be adequately preserved in the feedbunk for several days. This observation is typical of bermudagrass silages, which usually undergo heterolactic fermentation, resulting in the production of antimycotic acids like acetic acid that ensure the stability of the silage (Bates et al., 1989; Adesogan et al., 2004).

Dry matter losses were lower in the Pr-treated silages than in the other silages $(P<0.05)$. Though there was no effect of increasing Pr application on DM lost, this work demonstrates that Pr can be used to reduce the losses of DM that usually occur when bermudagrass is conserved as silage. Although DM losses decreased linearly $(P<0.05)$ as the rate of A20 application in- 
Table 2. Effect $^{1}$ of fibrolytic enzymes on $\mathrm{pH}$, concentrations of $\mathrm{DM}(\mathrm{g} / \mathrm{kg})$ and ammonia- $\mathrm{N}(\mathrm{g} / \mathrm{kg}$ of total N), DM losses (\%), microbial counts (log cfu/g), and aerobic stability (h) of bermudagrass silage.

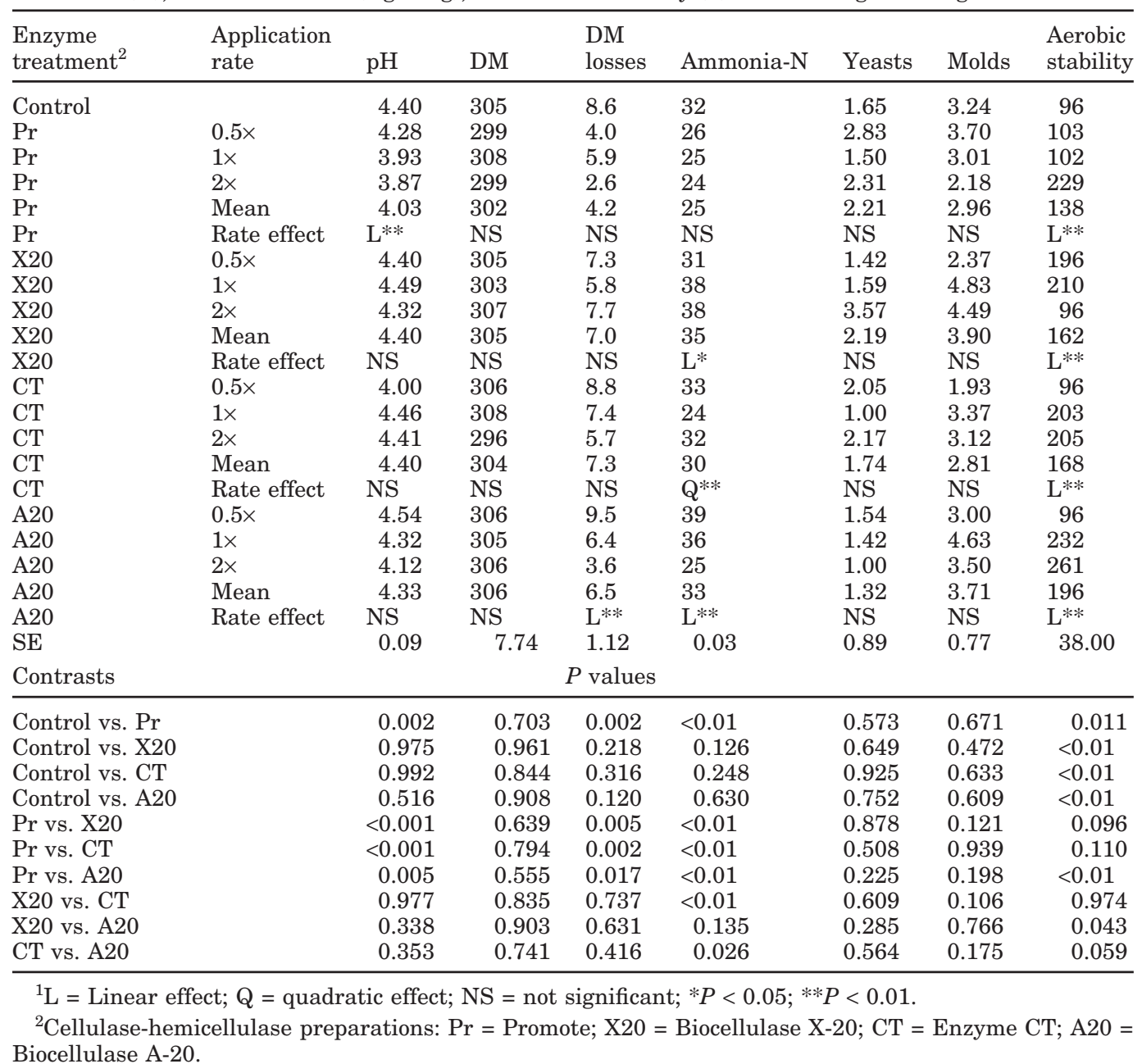

creased, the mean DM loss for A20-treated silages was similar to that of control silages.

Neither enzyme type nor application rate affected $(P$ $>0.05$ ) the ash content of the silages (Table 3). Compared with control silages, NDF concentration was reduced by $\operatorname{Pr}(P<0.01), \mathrm{X} 20$, and $\mathrm{CT}(P<0.05)$. However, the lowest NDF values $(P<0.001)$ were observed in the Pr-treated silages $(P<0.01)$, indicating that this treatment was the most effective at reducing the total fiber fraction. Silages treated with CT had lower $(P<$ 0.05 ) hemicellulose concentrations than other silages. As the rate of $\mathrm{CT}$ application increased, hemicellulose concentration decreased linearly $(P<0.01)$, and ADF concentration increased linearly $(P<0.01)$. This suggests that CT hydrolyzed the digestible fiber fraction in the silage but did not affect the less-digestible ADF fraction. Silages treated with $\operatorname{Pr}$ had lower $(P<0.001)$ $\mathrm{ADF}$ concentrations than control silages and other en- zyme-treated silages, suggesting that this treatment was particularly effective at reducing the concentration of the ADF fraction, which is usually digested poorly by ruminants. Treatment with Pr therefore reduced the total and less-digestible fiber fractions, and could potentially result in improved use of the fiber fraction in dairy cows fed bermudagrass silage. Although CT treatment reduced the total fiber fraction, it also reduced the digestible fiber concentration, which is an important source of slowly released energy for cattle in the southeast.

The reductions in NDF and $\mathrm{ADF}$ concentration by $\mathrm{Pr}$ and X20 treatment, and reductions in NDF and hemicellulose concentration by CT treatment, contradict the findings of Mandebvu et al. (1999) on bermudagrass. However, these results concur with previous observations on enzyme-treated wheat silage (Adogla-Bessa et al., 1999), corn silage (Sheperd and Kung, 1996a, b; 
Table 3. Effect ${ }^{1}$ of fibrolytic enzymes on the chemical composition of bermudagrass silage ( $\mathrm{g} / \mathrm{kg}$ of DM).

\begin{tabular}{|c|c|c|c|c|c|c|c|c|}
\hline $\begin{array}{l}\text { Enzyme } \\
\text { treatment }^{2}\end{array}$ & $\begin{array}{l}\text { Application } \\
\text { rate }\end{array}$ & $\mathrm{CP}$ & Ash & $\mathrm{NDF}$ & $\mathrm{ADF}$ & $\mathrm{Hem}^{3}$ & $\mathrm{WSC}^{4}$ & $\mathrm{WSN}^{5}$ \\
\hline Control & & 97 & 53 & 753 & 431 & 323 & 4.5 & 0.84 \\
\hline $\operatorname{Pr}$ & $0.5 \times$ & 96 & 49 & 723 & 408 & 315 & 8.2 & 0.73 \\
\hline $\operatorname{Pr}$ & $1 \times$ & 92 & 50 & 725 & 408 & 317 & 12.6 & 0.88 \\
\hline $\operatorname{Pr}$ & $2 \times$ & 93 & 54 & 728 & 408 & 319 & 15.9 & 0.73 \\
\hline $\operatorname{Pr}$ & Mean & 94 & 51 & 725 & 408 & 317 & 12.2 & 0.78 \\
\hline $\mathrm{Pr}$ & Rate effect & NS & NS & NS & NS & NS & $\mathrm{L}^{* *}$ & NS \\
\hline $\mathrm{X} 20$ & $0.5 \times$ & 98 & 61 & 744 & 420 & 324 & 6.1 & 0.71 \\
\hline $\mathrm{X} 20$ & $1 \times$ & 96 & 53 & 738 & 426 & 313 & 6.1 & 0.70 \\
\hline $\mathrm{X} 20$ & $2 \times$ & 97 & 51 & 747 & 426 & 321 & 5.9 & 0.89 \\
\hline $\mathrm{X} 20$ & Mean & 97 & 55 & 743 & 424 & 319 & 6.0 & 0.77 \\
\hline $\mathrm{X} 20$ & Rate effect & NS & NS & NS & NS & NS & NS & NS \\
\hline CT & $0.5 \times$ & 99 & 53 & 750 & 422 & 327 & 5.3 & 0.86 \\
\hline CT & $1 \times$ & 105 & 53 & 743 & 444 & 299 & 7.1 & 0.62 \\
\hline $\mathrm{CT}$ & $2 \times$ & 89 & 54 & 736 & 442 & 295 & 8.5 & 0.70 \\
\hline CT & Mean & 98 & 53 & 743 & 436 & 307 & 6.9 & 0.73 \\
\hline $\mathrm{CT}$ & Rate effect & $\mathrm{Q}^{* *}$ & NS & $\mathrm{L}^{* *}$ & $\mathrm{~L}^{* *}$ & $\mathrm{~L}^{*}$ & $\mathrm{~L}^{*}$ & NS \\
\hline A20 & $0.5 \times$ & 96 & 54 & 761 & 448 & 313 & 5.3 & 0.76 \\
\hline A20 & $1 \times$ & 95 & 54 & 757 & 438 & 319 & 5.3 & 0.67 \\
\hline A20 & $2 \times$ & 97 & 57 & 741 & 428 & 312 & 5.2 & 0.57 \\
\hline A20 & Mean & 96 & 55 & 753 & 438 & 315 & 5.3 & 0.67 \\
\hline A20 & Rate effect & NS & NS & $\mathrm{L}^{* *}$ & $\mathrm{~L}^{* *}$ & NS & NS & NS \\
\hline $\mathrm{SE}$ & & 1.64 & 2.29 & 3.36 & 2.70 & 3.84 & 0.81 & 0.07 \\
\hline Contrasts & \multicolumn{8}{|c|}{$P$ values } \\
\hline Control vs. Pr & & 0.125 & 0.386 & $<0.001$ & $<0.001$ & 0.204 & $<0.001$ & 0.466 \\
\hline Control vs. X20 & & 0.954 & 0.590 & 0.016 & 0.004 & 0.444 & 0.109 & 0.350 \\
\hline Control vs. CT & & 0.602 & 0.934 & 0.015 & 0.105 & 0.002 & 0.014 & 0.170 \\
\hline Control vs. A20 & & 0.816 & 0.508 & 0.977 & 0.022 & 0.078 & 0.407 & 0.039 \\
\hline Pr vs. X20 & & 0.028 & 0.054 & $<0.001$ & $<0.001$ & 0.463 & $<0.001$ & 0.766 \\
\hline Pr vs. CT & & 0.006 & 0.269 & $<0.001$ & $<0.001$ & 0.004 & $<0.001$ & 0.351 \\
\hline Pr vs. A20 & & 0.067 & 0.071 & $<0.001$ & $<0.001$ & 0.463 & $<0.001$ & 0.053 \\
\hline $\mathrm{X} 20$ vs. CT & & 0.513 & 0.381 & 0.968 & $<0.001$ & 0.001 & 0.179 & 0.522 \\
\hline X20 vs. A20 & & 0.682 & 0.860 & 0.001 & $<0.001$ & 0.149 & 0.260 & 0.097 \\
\hline CT vs. A20 & & 0.291 & 0.295 & 0.001 & 0.299 & 0.022 & 0.018 & 0.293 \\
\hline
\end{tabular}

${ }^{1} \mathrm{~L}=$ Linear effect; $\mathrm{Q}=$ quadratic effect; $\mathrm{NS}=$ not significant; $* P<0.05 ; * * P<0.01$.

${ }^{2}$ Cellulase-hemicellulase preparations: $\mathrm{Pr}=$ Promote; X20 = Biocellulase X-20; CT = Enzyme CT; A20 = Biocellulase A-20.

${ }^{3} \mathrm{Hem}=$ Hemicellulose.

${ }^{4} \mathrm{WSC}=$ Water-soluble carbohydrates.

${ }^{5} \mathrm{WSN}=$ Water-soluble nitrogen.

Colombatto et al., 2004), and orchardgrass or alfalfa silages (Nadeau et al., 2000). Differences between the effects of enzymes on cell wall hydrolysis in bermudagrass silage in this study and that of Mandebvu et al. (1999) may be due to differences in enzyme activity. These results therefore provide new evidence that fibrolytic enzymes can enhance cell wall hydrolysis in C4 grasses, as is the case in C3 grasses.

Silages treated with $\operatorname{Pr}(P<0.01)$ and CT $(P<0.05)$ had greater residual WSC concentration than control silages. As the rate of application of both of these enzymes increased, residual WSC concentration increased linearly $(P<0.05)$. However, these enzymes increased residual WSC concentration by hydrolyzing different fiber fractions. Whereas Pr hydrolyzed the less-digestible fiber fraction, CT reduced the digestible fiber fraction. Therefore, both of these enzymes were effective in increasing the availability of fermentation substrates, but $\operatorname{Pr}$ was potentially more beneficial at improving the digestibility of the silages.

The WSC values obtained in the Pr-treated silages are higher than those reported by Adesogan et al. (2004), probably because of greater cellulase and xylanase activity in Pr than in the enzyme included in the inoculant used by Adesogan et al. (2004). The increase in WSC concentration of enzyme-treated silages agrees with results obtained by Sheperd and Kung (1996a), Adogla-Bessa et al. (1999), and Nadeau et al. (2000). Colombatto et al. (2003) observed that addition of fibrolytic enzymes increased $(P<0.01)$ release of reducing sugars from fibrous fractions of forage during a $20-\mathrm{h}$ preincubation phase.

The concentration of CP was similar in enzymetreated and control silages (Table 4). However, CP con- 
Table 4. Effect $^{1}$ of fibrolytic enzymes on the organic acid concentration ( $\mathrm{g} / \mathrm{kg}$ of DM) of bermudagrass silage.

\begin{tabular}{|c|c|c|c|c|c|c|}
\hline $\begin{array}{l}\text { Enzyme } \\
\text { treatment }^{2}\end{array}$ & $\begin{array}{l}\text { Application } \\
\text { rate }\end{array}$ & $\begin{array}{l}\text { Lactic } \\
\text { acid }\end{array}$ & $\begin{array}{l}\text { Acetic } \\
\text { acid }\end{array}$ & $\begin{array}{l}\text { Isobutyric } \\
\text { acid }\end{array}$ & $\begin{array}{l}\text { Butyric } \\
\text { acid }\end{array}$ & $\begin{array}{l}\text { Isovaleric } \\
\text { acid }\end{array}$ \\
\hline Control & & 50 & 46 & 54 & 7.1 & 11 \\
\hline $\operatorname{Pr}$ & $0.5 \times$ & 83 & 29 & 63 & 7.7 & 17 \\
\hline $\operatorname{Pr}$ & $1 \times$ & 54 & 13 & 37 & 0.57 & 8 \\
\hline $\operatorname{Pr}$ & $2 \times$ & 60 & 15 & 46 & 0 & 10 \\
\hline $\operatorname{Pr}$ & Mean & 66 & 19 & 48 & 2.8 & 11 \\
\hline $\operatorname{Pr}$ & Rate effect & NS & $\mathrm{L}^{* *}$ & NS & $\mathrm{L}^{* *}$ & $\mathrm{~L}^{*}$ \\
\hline $\mathrm{X} 20$ & $0.5 \times$ & 32 & 22 & 34 & 3.9 & 8 \\
\hline $\mathrm{X} 20$ & $1 \times$ & 49 & 38 & 42 & 5.9 & 9 \\
\hline $\mathrm{X} 20$ & $2 \times$ & 64 & 38 & 53 & 5.9 & 13 \\
\hline $\mathrm{X} 20$ & Mean & 48 & 33 & 43 & 5.3 & 10 \\
\hline $\mathrm{X} 20$ & Rate effect & $\mathrm{L}^{*}$ & $\mathrm{~L}^{* *}$ & NS & NS & NS \\
\hline CT & $0.5 \times$ & 57 & 38 & 46 & 5.8 & 11 \\
\hline CT & $1 \times$ & 54 & 36 & 68 & 0 & 18 \\
\hline $\mathrm{CT}$ & $2 \times$ & 57 & 32 & 58 & 4.9 & 14 \\
\hline $\mathrm{CT}$ & Mean & 56 & 35 & 57 & 3.6 & 14 \\
\hline CT & Rate effect & NS & NS & NS & $\mathrm{Q}^{*}$ & $\mathrm{Q}^{*}$ \\
\hline A20 & $0.5 \times$ & 44 & 42 & 54 & 8.1 & 12 \\
\hline A20 & $1 \times$ & 62 & 35 & 59 & 9.2 & 14 \\
\hline A20 & $2 \times$ & 64 & 33 & 76 & 0 & 14 \\
\hline A20 & Mean & 56 & 37 & 63 & 5.7 & 13 \\
\hline A20 & Rate effect & NS & NS & $\mathrm{L}^{*}$ & $\mathrm{~L}^{* *}$ & NS \\
\hline $\mathrm{SE}$ & & 10.61 & 3.36 & 7.41 & 1.96 & 1.97 \\
\hline Contrasts & & \multicolumn{5}{|c|}{$P$ values } \\
\hline Control vs. Pr & & 0.211 & $<0.001$ & 0.504 & 0.064 & 0.735 \\
\hline Control vs. X20 & & 0.899 & 0.002 & 0.213 & 0.414 & 0.915 \\
\hline Control vs. CT & & 0.635 & 0.012 & 0.690 & 0.129 & 0.126 \\
\hline Control vs. A20 & & 0.612 & 0.028 & 0.287 & 0.551 & 0.210 \\
\hline Pr vs. X20 & & 0.057 & $<0.001$ & 0.372 & 0.130 & 0.531 \\
\hline Pr vs. CT & & 0.267 & $<0.001$ & 0.154 & 0.607 & 0.091 \\
\hline Pr vs. A20 & & 0.287 & $<0.001$ & 0.022 & 0.071 & 0.194 \\
\hline $\mathrm{X} 20$ vs. CT & & 0.398 & 0.366 & 0.025 & 0.307 & 0.024 \\
\hline X20 vs. A20 & & 0.373 & 0.159 & 0.003 & 0.752 & 0.060 \\
\hline CT vs. A20 & & 0.963 & 0.600 & 0.342 & 0.185 & 0.677 \\
\hline
\end{tabular}

${ }^{1} \mathrm{~L}=$ Linear effect; $\mathrm{Q}=$ quadratic effect; $\mathrm{NS}=$ not significant; $* P<0.05 ; * * P<0.01$

${ }^{2}$ Cellulase-hemicellulase preparations: $\operatorname{Pr}=$ Promote; X20 = Biocellulase X-20; CT = Enzyme CT; A20 = Biocellulase A-20.

centration was lower in Pr-treated silages than silages treated with $\mathrm{X} 20(P<0.05)$ and $\mathrm{CT}(P<0.01)$. This numerically small difference in $\mathrm{CP}$ did not result from greater proteolysis in Pr-treated silages because they had lower $(P<0.05)$ ammonia-N concentrations than the other silages. Rather, it may have been due to the higher WSC concentration of Pr-treated silages.

\section{Organic Acid Concentration of Bermudagrass Silages}

The lactic acid concentrations (Table 4) of the control and enzyme-treated silages were similar $(P>0.05)$. However, the lactic acid concentration of Pr-, CT-, and A20-treated silages was 32,12 , and $12 \%$ greater, respectively, than that of the control silage. These results agree with those obtained by Mandebvu et al. (1999) who found that, although fibrolytic enzyme treatment of bermudagrass did not increase lactic acid concentration, values for enzyme-treated forages were $5.4 \%$ higher than for untreated forage. The numerically greater lactic acid concentrations in this study, particularly for Pr and CT, reflect the higher residual WSC concentration of silages treated with these enzymes, because WSC is the primary fermentable substrate used by lactic acid bacteria in silages.

Acetic acid concentration was lower $(P<0.01)$ in enzyme-treated silages than in control silages. Promotetreated silages had the lowest $(P<0.001)$ acetic acid concentrations. Unlike other enzymes, increases in the rate of $\operatorname{Pr}$ application decreased $(P<0.05)$ acetic acid concentration linearly. These results contrast with those of Sheperd and Kung (1996a) and Mandebvu et al. (1999), who found no effect of fibrolytic enzyme treatment on acetic acid concentration of silages. The lower acetic acid concentration $(P<0.01)$ and numerically higher lactic acid concentration in Pr-treated silages suggests that $\mathrm{Pr}$ enhanced homofermentative processes during ensiling, which reduced $\mathrm{CO}_{2}$ formation and therefore minimized DM and energy losses. These fac- 
Table 5. Effect of fibrolytic enzymes on in vitro digestibility of DM (g/kg), NDF, ADF, and hemicellulose $(\mathrm{Hem})$ in bermudagrass silage after 6 or $48 \mathrm{~h}$ of digestion $(\mathrm{g} / \mathrm{kg}$ of $\mathrm{DM})$.

\begin{tabular}{|c|c|c|c|c|c|c|}
\hline $\begin{array}{l}\text { Enzyme } \\
\text { treatment }^{1}\end{array}$ & $\begin{array}{l}\text { Appliation } \\
\text { rate }\end{array}$ & $\begin{array}{l}\mathrm{DM} \\
6 \mathrm{~h}\end{array}$ & $\begin{array}{l}\mathrm{DM} \\
48 \mathrm{~h}\end{array}$ & $\begin{array}{l}\text { NDF } \\
48 \mathrm{~h}\end{array}$ & $\begin{array}{l}\mathrm{ADF} \\
48 \mathrm{~h}\end{array}$ & $\begin{array}{l}\text { Hem } \\
48 \mathrm{~h}\end{array}$ \\
\hline Control & & 200 & 501 & 402 & 427 & 368 \\
\hline $\operatorname{Pr}$ & $0.5 \times$ & 227 & 561 & 461 & 489 & 425 \\
\hline $\operatorname{Pr}$ & $1 \times$ & 223 & 546 & 442 & 457 & 423 \\
\hline $\mathrm{Pr}$ & $2 \times$ & 225 & 554 & 448 & 442 & 456 \\
\hline $\operatorname{Pr}$ & Mean & 225 & 554 & 450 & 462 & 435 \\
\hline $\operatorname{Pr}$ & Rate effect & NS & NS & NS & $\mathrm{L}^{*}$ & NS \\
\hline $\mathrm{X} 20$ & $0.5 \times$ & 208 & 498 & 393 & 414 & 365 \\
\hline X20 & $1 \times$ & 195 & 498 & 370 & 426 & 344 \\
\hline $\mathrm{X} 20$ & $2 \times$ & 209 & 495 & 385 & 405 & 360 \\
\hline $\mathrm{X} 20$ & Mean & 204 & 497 & 383 & 415 & 356 \\
\hline $\mathrm{X} 20$ & Rate effect & $\mathrm{Q}^{*}$ & NS & NS & NS & $\mathrm{Q}^{* *}$ \\
\hline CT & $0.5 \times$ & 198 & 487 & 385 & 401 & 363 \\
\hline $\mathrm{CT}$ & $1 \times$ & 199 & 536 & 447 & 512 & 342 \\
\hline CT & $2 \times$ & 205 & 521 & 416 & 479 & 321 \\
\hline $\mathrm{CT}$ & Mean & 201 & 515 & 416 & 464 & 342 \\
\hline $\mathrm{CT}$ & Rate effect & NS & $\mathrm{L}^{* *}$ & $\mathrm{Q}^{* *}$ & $\mathrm{~L}^{* *}$ & NS \\
\hline A20 & $0.5 \times$ & 183 & 502 & 424 & 462 & 369 \\
\hline A20 & $1 \times$ & 190 & 491 & 399 & 436 & 349 \\
\hline $\mathrm{A} 20$ & $2 \times$ & 184 & 538 & 464 & 504 & 411 \\
\hline A20 & Mean & 186 & 510 & 429 & 467 & 376 \\
\hline $\mathrm{A} 20$ & Rate effect & NS & $\mathrm{L}^{* *}$ & $\mathrm{Q}^{* *}$ & $\mathrm{Q}^{* *}$ & NS \\
\hline $\mathrm{SE}$ & & 4.398 & 8.290 & 13.102 & 13.295 & 13.134 \\
\hline Contrasts & & & & $P$ values & & \\
\hline Control vs. Pr & & $<0.001$ & $<0.001$ & 0.004 & 0.032 & 0.007 \\
\hline Control vs. X20 & & 0.401 & 0.638 & 0.215 & 0.425 & 0.206 \\
\hline Control vs. CT & & 0.897 & 0.176 & 0.371 & 0.026 & 0.264 \\
\hline Control vs. A20 & & 0.009 & 0.350 & 0.085 & 0.017 & 0.724 \\
\hline Pr vs. X20 & & $<0.001$ & $<0.001$ & $<0.001$ & 0.000 & $<0.001$ \\
\hline Pr vs. CT & & $<0.001$ & $<0.001$ & 0.003 & 0.895 & $<0.001$ \\
\hline Pr vs. A20 & & $<0.001$ & $<0.001$ & 0.059 & 0.686 & 0.001 \\
\hline X20 vs. CT & & 0.317 & 0.014 & 0.005 & 0.000 & 0.826 \\
\hline $\mathrm{X} 20$ vs. $\mathrm{A} 20$ & & $<0.001$ & 0.054 & 0.000 & $<0.001$ & 0.027 \\
\hline CT vs. A20 & & 0.000 & 0.538 & 0.224 & 0.785 & 0.044 \\
\hline
\end{tabular}

\footnotetext{
${ }^{1} \mathrm{~L}=$ Linear effect; $\mathrm{Q}=$ quadratic effect; $\mathrm{NS}=$ not significant; $* P<0.05 ; * * P<0.01$.

${ }^{2}$ Cellulase-hemicellulase preparations: $\mathrm{Pr}=$ Promote; X20 = Biocellulase X-20; CT = Enzyme CT; A20 = Biocellulase A-20.
}

tors are partly responsible for the lower $(P<0.05) \mathrm{DM}$ losses in the Pr-treated silages relative to those in the other silages. However, the tendency toward greater homofermentative processes in enzyme-treated forages conflicts with their greater aerobic stability, as homofermentative silages are often more susceptible to aerobic spoilage. The reason for this anomaly is not clear. Nevertheless, the extent of enzyme-induced homofermentation was not sufficient to override the inherent heterofermentation and aerobic stability of bermudagrass silage.

Butyric acid was found in all the silages except those treated with $\mathrm{Pr}$ and A20 at twice the recommended rate and $\mathrm{CT}$ at the recommended rate. Butyric acid concentration decreased linearly $(P<0.05)$ with increasing application of $\mathrm{Pr}, \mathrm{A} 20$, and CT. However, only Pr treatment produced butyric acid concentrations that tended to be less $(P=0.064)$ than those in control silages. The decrease in butyric acid concentration follow- ing Pr treatment supports the observations of AdoglaBessa et al. (1999) on wheat silage, but contradicts those of Mandebvu et al. (1999) on bermudagrass silage. This discrepancy is attributable to the high cellulase and xylanase activities in Pr, which resulted in substantial hydrolysis of cell walls into WSC. When the concentration of such WSC is adequate, and moisture is not excessive, homofermentative lactic acid bacteria proliferate rather than heterofermenters and clostridia, so that lactic acid accumulates instead of butyric acid.

The isobutyric acid concentrations of the treated and untreated silages were similar $(P<0.05)$. Neither propionic acid nor ethanol was found in the silages. The absence of ethanol in the silages may be explained by the low yeast counts and relatively low WSC concentrations in the silages, because yeasts are primarily responsible for ethanol production from the fermentation of sugars in silages. 


\section{In vitro DM and Fiber Digestibility of Bermudagrass Silages}

Unlike silages treated with the other enzymes, $\mathrm{Pr}$ treated silages had greater $(P<0.05) 6$ - and 48 -h IVDMD values as well as greater 48-h IVNDFD and IVADFD than control silages (Table 5). Silages treated with Pr consistently had greater 6- and 48-h IVDMD, and 48-h IVNDF values than those treated with the other enzymes. The increase in IVDMD at 6 - and 48-h by Pr treatment suggests that application of this enzyme can increase both the rate and extent of digestion of bermudagrass silage. Furthermore, Pr treatment was effective at improving the digestibility of the total digestible and less-digestible cell wall fractions, corroborating the earlier suggestion that Pr treatment could increase the use of bermudagrass silage by ruminants. Previous studies did not detect such benefits of enzyme treatment on the in vitro digestibility of DM and NDF of bermudagrass silage (Mandebvu et al., 1999) or the in vivo digestibility of orchardgrass silage (Nadeau et al., 2000). The IVADFD was greater in the Pr-, CT-, and A20-treated silages compared with control silages $(P<0.05)$ and X20 $(P<0.01)$. Therefore, these enzymes increased the susceptibility of the typically indigestible cell wall fraction to ruminal digestion. Hemicellulose digestibility was also greater in the Pr-treated silages $(P<0.01)$ than control silages or other enzyme-treated silages, whereas A20 showed higher values $(P<0.05)$ than X20.

The superior effect of Pr treatment in this study is, in part, attributable to the fact that in accordance with the each of the enzyme manufacturer's guidelines, a greater amount of enzyme was applied to the forages in the Pr treatment than in the other enzyme treatments. This is partly because Pr is supplied in liquid form, whereas the other enzymes were supplied in solid form. Although Pr did not have the highest xylanase or cellulase activity, it had greater combined cellulase and xylanase activity than the other enzymes. The synergistic effects of these enzymes in Pr probably accounted for its superior effects on the silages. Although no cellulase or xylanase activity was detected in $\mathrm{CT}$, the results of this study indicate that it had fibrolytic activity. Therefore, it probably contained different enzymes to those that were analyzed.

A follow-up study is currently investigating the effects of applying Pr to bermudagrass silages at ensiling, or to the forage concentrate or TMR of dairy cows at feeding, on the nutritive value of bermudagrass and the feed intake and milk production from the cows.

\section{CONCLUSIONS}

This study shows that the nutritive value and fermentation of bermudagrass silage can be improved by treating it with fibrolytic enzymes. Compared with control silages, enzyme-treated silages had greater WSC concentration due to hydrolysis of different cell wall fractions. However, Promote was the most promising enzyme for increasing residual WSC concentration enhancing homofermentation, and reducing $\mathrm{pH}, \mathrm{DM}$ losses, and proteolysis.

\section{ACKNOWLEDGMENTS}

This research was supported by the Florida Agricultural Experiment Station and grants from USDA CSREES T-STAR-C and the Florida Milk Check-Off Program, and was approved for publication as Journal Series No. R-10646. We gratefully acknowledge the assistance of D. Colombatto with the enzyme activity assays.

\section{REFERENCES}

Adesogan, A. T., N. K. Krueger, M. B. Salawu, D. B. Dean, and C. R. Staples. 2004. The influence of treatment with dual-purpose bacterial inoculants or soluble carbohydrates on the fermentation and aerobic stability of bermudagrass. J. Dairy Sci. 87:3407-3416.

Adogla-Bessa, T., E. Owen, and A. T. Adesogan. 1999. Ensiling of whole crop wheat with cellulase-hemicellulase based enzymes 3 . Comparing effects of urea or enzyme treatment on forage composition and stability. Anim. Feed Sci. Technol. 82:51-61.

Bailey, M. J., P. Biely, and K. Poutanen. 1992. Interlaboratory testing of methods for assay of xylanase activity. J. Biotechnol. $23: 257-270$

Bates, D. B., W. E. Kunkle, T. E. Dawson, A. Berthe, S. C. Denham, C. G. Chambliss, R. C. Cromwell, J. G. Wasdin, and D. L. Wakeman. 1989. Round bale silage-A forage harvesting alternative. Pages 45-50 in Proc. 38th Annual Beef Short Course. Univ. Florida, Gainesville, FL.

Beauchemin, K. A., D. Colombatto, D. P. Morgavi, and W. Z. Yang. 2003. Use of exogenous fibrolytic enzymes to improve feed utilization by ruminants. J. Anim. Sci. 81:E37-E 47.

Bowman, G. R., K. A. Beauchemin, and J. A. Shelford. 2002. The proportion of feed to which a fibrolytic enzyme additive is applied affects nutrient digestion by lactating dairy cows. J. Dairy Sci. 85:3420-3429.

Colombatto, D., F. L. Mould, M. K. Bhat, D. P. Morgavi, K. A. Beauchemin, and E. Owen. 2003. Influence of fibrolytic enzymes on the hydrolysis and fermentation of pure cellulose and xylan by mixed ruminal microorganisms in vitro. J. Anim. Sci. 81:1040-1050.

Colombatto, D., F. L. Mould, M. K. Bhat, R. H. Phipps, and E. Owen. 2004. In vitro evaluation of fibrolytic enzymes as additives for maize (Zea mays L.) silage. I. Effects of ensiling temperature, enzyme source and addition level. Anim. Feed Sci. Technol. 111:111-128.

Higginbotham, G. E., S. C. Mueller, K. K. Bolsen, and E. J. Peters. 1998. Effects of inoculants containing propionic acid bacteria on fermentation and aerobic stability of corn silage. J. Dairy Sci. $81: 2185-2192$.

Hristov, A. N., T. A. McAllister, and K. J. Cheng. 2000. Intraruminal supplementation with increasing rates of exogenous polysaccharide-degrading enzymes: Effects on nutrient digestion in cattle fed a barley grain diet. J. Anim. Sci. 78:477-487.

Kung, L., Jr. 2004. Improving the aerobic stability of silages. Animal and Food Sciences, University of Delaware, College of Agriculture and Natural Resources. Online. Available http://ag.udel.edu/departments/anfs/faculty/kung/articles/ improving_the_aerobic_stability.htm. Accessed Jan. 15, 2004. 
Kung, L., Jr., M. A. Cohen, L. M. Rode, and R. J. Treacher. 2002. The effect of fibrolytic enzymes sprayed onto forages and fed in a total mixed ratio to lactating dairy cows. J. Dairy Sci. 85:2396-2402.

Lewis, G. E., C. W. Hunt, W. K. Sanchez, R. Treacher, G. T. Pritchard, and P. Feng. 1996. Effect of direct-fed fibrolytic enzymes on the digestive characteristics of a forage-based diet fed to beef steers. J. Anim. Sci. 74:3020-3028.

Mandebvu, P., J. W. West, M. A. Froetschel, R. D. Hatfield, R. N. Gates, and G. M. Hill. 1999. Effect of enzyme or microbial treatments of bermudagrass forages before ensiling on cell wall composition, end products of silage fermentation and in situ digestion kinetics. Anim. Feed Sci. Technol. 77:317-329.

Ministry of Agriculture, Fisheries and Food (MAFF). 1986. The Analysis of Agricultural Materials. Reference Book 427. HMSO, London, UK.

Morgavi, D. P., V. L. Nsereko, L. M. Rode, K. A. Beauchemin, T. A. McAllister, and Y. Wang. 2000. Effect of Trichoderma feed enzyme on growth and substrate degradation by Fibrobacter succinogens F85. Reprod. Nutr. Dev. 40:219.

Muck, R. E., and J. T. Dickerson. 1988. Storage temperature effects on proteolysis in alfalfa silage. Trans. ASAE 31:1005-1009.

Nadeau, E. M., J. R. Russell, and D. R. Buxton. 2000. Intake, digestibility, and composition of orchardgrass and alfalfa silages treated with cellulase, inoculant and formic acid fed to lambs. J. Anim. Sci. 78:2980-2989.

Noel, R. J., and L. G. Hambleton. 1976. Collaborative study of a semiautomated method for determination of crude protein in animal feeds. J. AOAC 59:134-140.

Nsereko, V. L., D. P. Morgavi, K. A. Beauchemin, L. M. Rode, A. F. Furtado, and T. A. McAllister. 2000. Effects of feeding fungal feed enzyme preparation on the rumen microbial population. Reprod. Nutr. Dev. 40:219-225.

Schingoethe, D. J., G. A. Stegeman, and R. J. Treacher. 1999. Response of lactating dairy cows to a cellulase and xylanase enzyme mixture applied to forages at the time of feeding. J. Dairy Sci. 82:996-1003.

Sheperd, A. C., and L. Kung, Jr. 1996a. Effects of an enzyme additive on composition of corn silage ensiled at various stages of maturity. J. Dairy Sci. 79:1767-1773.

Sheperd, A. C., and L. Kung, Jr. 1996b. An enzyme additive for corn silage: Effects on silage composition and animal performance. J. Dairy Sci. 79:1760-1766.

Tournas, V., M. E. Stack, P. B. Mislivec, H. A. Koch, and R. Bandler. 1998. Yeasts, molds and mycotoxins. Pages 18.01-18.09 in Food and Drug Administration Bacteriological Analytical Manual. AOAC International, Gaithersburg, MD.

Umana, R., C. R. Staples, D. B. Bates, C. J. Wilcox, and W. C. Mahanna. 1991. Effects of a microbial inoculant and (or) sugarcane molasses on the fermentation, aerobic stability and digestibility of bermudagrass ensiled at two moisture contents. J. Anim. Sci. 69:4588-4601.

Van Soest, P. J., J. B. Robertson, and B. A. Lewis. 1991. Methods for dietary fiber, neutral detergent fiber and non-starch polysaccharides in relation to animal nutrition. J. Dairy Sci. 74:35683597.

Vicini, J. L., H. G. Bateman, M. K. Bhat, J. H. Clark, R. A. Erdman, R. H. Phipps, M. E. Van Amburgh, G. F. Hartnell, R. L. Hintz, and D. L. Hard. 2003. Effect of feeding supplemental fibrolytic enzymes or soluble sugars with malic acid on milk production. J. Dairy Sci. 86:576-585.

Wood, T. M., and M. K. Bhat. 1988. Methods for measuring cellulase activities. Vol. 160. Pages 87-112 in Methods in Enzymology. W. A. Wood and S. T. Kellogg, ed. Academic Press, London, UK.

Yang, W. Z., K. A. Beauchemin, and L. M. Rode. 1999. Effects of an enzyme feed additive on extent of digestion and milk production of lactating dairy cows. J. Dairy Sci. 82:391-403.

Yomano, L. P., S. W. York, and L. O. Ingram. 1998. Isolation and characterization of ethanol-tolerant mutants of Escherichia coli for fuel ethanol production. J. Ind. Microbiol. Biotechnol. $20: 132-138$ 